Prepared in cooperation with the Yakama Nation

\title{
An Annotated Bibliography for Lamprey Habitat in the White Salmon River, Washington
}

Open-File Report 2012-1086 



\section{An Annotated Bibliography for Lamprey Habitat in the White Salmon River, Washington}

By M. Brady Allen

Prepared in cooperation with the Yakama Nation

Open-File Report 2012-1086

U.S. Department of the Interior

U.S. Geological Survey 


\section{U.S. Department of the Interior \\ KEN SALAZAR, Secretary}

\section{U.S. Geological Survey \\ Marcia K. McNutt, Director}

U.S. Geological Survey, Reston, Virginia: 2012

For more information on the USGS-the Federal source for science about the Earth, its natural and living resources, natural hazards, and the environment, visit http://www.usgs.gov or call 1-888-ASK-USGS.

For an overview of USGS information products, including maps, imagery, and publications, visit http://www.usgs.gov/pubprod

To order this and other USGS information products, visit http://store.usgs.gov

Suggested citation:

Allen, M.B., 2012, An annotated bibliography for lamprey habitat in the White Salmon River, Washington: U.S. Geological Survey Open-File Report 2012-1086, 28 p.

Any use of trade, product, or firm names is for descriptive purposes only and does not imply endorsement by the U.S. Government.

Although this report is in the public domain, permission must be secured from the individual copyright owners to reproduce any copyrighted material contained within this report. 


\section{Contents}

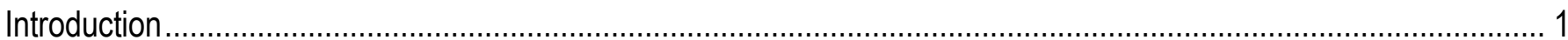

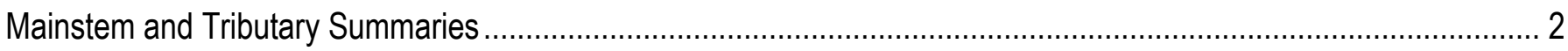

White Salmon River below BZ Falls (rkm 0 to 20)

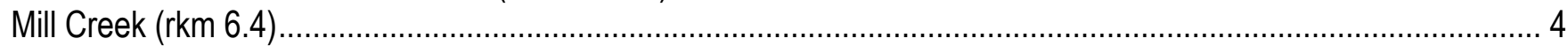

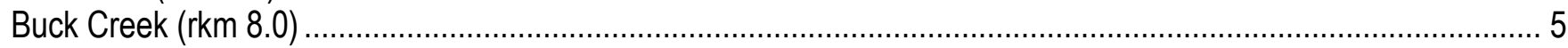

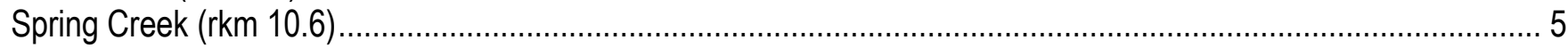

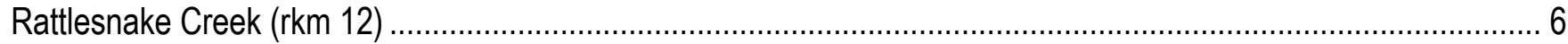

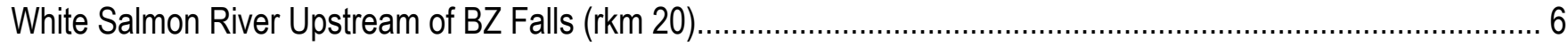

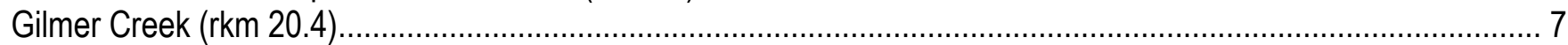

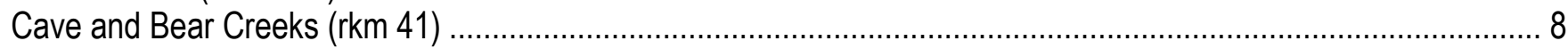

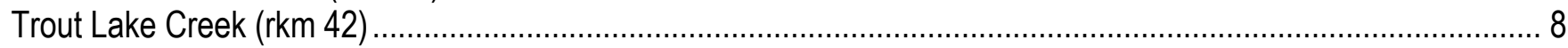

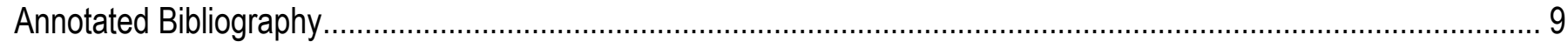

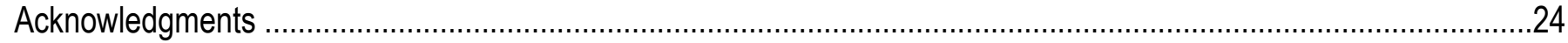

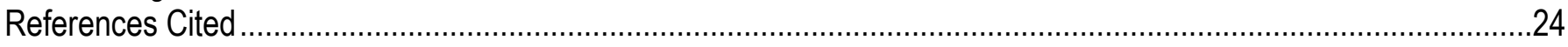

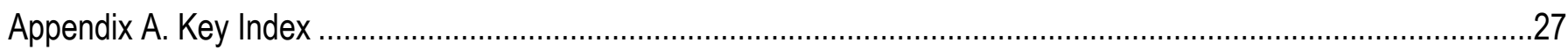

\section{Figure}

Figure 1. Map showing White Salmon River, its main tributaries, U.S. Forest Service boundary, and waterfalls that have potential to be barriers to fish migration, Washington 


\section{Conversion Factors}

Inch/Pound to SI

\begin{tabular}{lll}
\hline \multicolumn{1}{c}{ Multiply } & \multicolumn{1}{c}{ By } & \multicolumn{1}{c}{ To obtain } \\
\hline centimeter $(\mathrm{cm})$ & 0.3937 & inch (in.) \\
meter $(\mathrm{m})$ & 3.281 & foot $(\mathrm{ft})$ \\
kilometer $(\mathrm{km})$ & 0.6214 & mile $(\mathrm{mi})$ \\
square kilometer $\left(\mathrm{km}^{2}\right)$ & 0.3861 & square mile $\left(\mathrm{mi}^{2}\right)$ \\
cubic foot per second $\left(\mathrm{ft}^{3} / \mathrm{s}\right)$ & 0.02832 & cubic meter per second $\left(\mathrm{m}^{3} / \mathrm{s}\right)$ \\
\hline
\end{tabular}

Temperature in degrees Celsius $\left({ }^{\circ} \mathrm{C}\right)$ may be converted to degrees Fahrenheit $\left({ }^{\circ} \mathrm{F}\right)$ as follows:

${ }^{\circ} \mathrm{F}=\left(1.8 \mathrm{x}^{\circ} \mathrm{C}\right)+32$

SI to Inch/Pound

\begin{tabular}{lcll}
\hline \multicolumn{1}{c}{ Multiply } & By & To obtain \\
\hline centimeter $(\mathrm{cm})$ & 0.3937 & inch (in.) \\
millimeter (mm) & 0.03937 & inch (in.) \\
meter (m) & 3.281 & foot (ft) \\
kilometer $(\mathrm{km})$ & 0.6214 & mile (mi) \\
hectare (ha) & 2.471 & acre \\
square kilometer $\left(\mathrm{km}^{2}\right)$ & 247.1 & acre & \\
\hline
\end{tabular}




\title{
An Annotated Bibliography for Lamprey Habitat in the White Salmon River, Washington
}

\author{
By M. Brady Allen
}

\section{Introduction}

The October 2011 decommissioning of Condit Dam on the White Salmon River at river kilometer ( $\mathrm{rkm}) 5.3$ removed a significant fish passage barrier from the White Salmon River basin for the first time in nearly a century. This affords an opportunity to regain a potentially important drainage basin for Pacific lamprey (Entosphenus tridentatus) production. In anticipation of Pacific lamprey recolonization or reintroduction, aquatic resource managers, such as the Yakama Nation (YN), are planning to perform surveys in the White Salmon River and its tributaries. The likely survey objectives will be to investigate the presence of lamprey, habitat conditions, and habitat availability. In preparation for this work, a compilation and review of the relevant aquatic habitat and biological information on the White Salmon River was conducted. References specific to the White Salmon River were collected and an annotated bibliography was produced including reports containing:

- Spatial information about where various habitat surveys or monitoring have occurred over the past 20 years;

- Database information relevant to habitat attributes (for example, pools, riffles, or glides);

- Riparian surveys along major tributary streams;

- Water temperature and sediment information;

- Lamprey surveys, observations, and collections;

- Spawning gravel surveys; and

- Surveys that inventory habitat degradation or other environmental factors that may limit potential future productivity of lamprey.

The understanding of lamprey habitat needs in 2012 is insufficient to determine all habitat factors that may benefit or limit lamprey productivity. It is known that adult Pacific lamprey generally arrive at their spawning grounds in midsummer and spawn the following spring (Kan, 1975; Beamish, 1980). Eggs typically hatch into ammocoetes in 2-3 weeks (Close and others, 2002). These filterfeeding larvae drift downstream and bury themselves in silt, mud, or fine gravel along the margins and backwaters of streams and rivers (Kan, 1975). Pacific lamprey need habitats with flows that are gentle to moderate, interspersed small gravel beds for spawning, silt areas for burrowing, and depositional areas for food, such as organic debris, bacteria, and algae (Kostow, 2002). Habitat studies have shown that larval lampreys are associated with patchy fluvial features, such as backwaters, eddies, insides of bends, and the downstream end of sand bars, in which fine sediments (sand and silt) tend to accumulate 
(Torgersen and Close, 2004). Ammocoetes generally spend 4-6 years in fresh water (Kan, 1975; Close and others, 2002). Prior to outmigrating in the fall, ammocoetes metamorphose into macrophthalmia, which resemble the adult form. Pacific lamprey macrophthalmia in the Columbia River may use spring flows to aid in carrying them to the ocean (Kan, 1975; Beamish, 1980). Beyond this basic knowledge, the current understanding of their habitat needs is poor. Some habitat needs of Pacific lamprey and steelhead (Oncorhynchus mykiss) overlap (Luzier and others, 2011); therefore, we largely used steelhead habitat needs to indicate the relevance of literature surveyed for inclusion in this report.

The physical characteristics of waterfalls over which Pacific lamprey can pass are not understood at the time of this writing. Pacific lamprey can ascend some waterfalls — such as Willamette Falls on the Willamette River, Sherars Falls on the Deschutes River, and Tumwater Falls on the John Day River - that also are passable to some anadromous salmonids during certain flow conditions (Kostow, 2002). However, it does not appear that Pacific lamprey can ascend waterfalls on some nearby rivers, such as the Wind River (Shipherd Falls, which steelhead can ascend) or the Little White Salmon River (Spirit Falls, which no fish are known to ascend), because Pacific lamprey have not been found in these rivers above these falls (Charlie Cochran, Washington Department of Fish and Wildlife, oral commun., 2012. However, distribution of Pacific lamprey above waterfalls has not been well documented. The White Salmon River has numerous waterfalls that are potential barriers for anadromous salmonids, and these also may be partial or complete barriers to Pacific lamprey (fig. 1).

The objective of this project was to acquire and summarize existing reports and data summaries associated with the White Salmon River that may provide information about its potential suitability for Pacific lamprey. This report is intended to assist with information-gathering in preparation for assessing the population status of Pacific lamprey and planning for their recovery in the White Salmon River.

\section{Mainstem and Tributary Summaries}

\section{White Salmon River below BZ Falls (rkm 0 to 20)}

In general, the mainstem White Salmon River has good water quantity and quality. The White Salmon River basin is approximately $1,000 \mathrm{~km}^{2}$. Peak flows in the mainstem reflect snowmelt runoff, increasing from an average daily flow of $644 \mathrm{ft}^{3} / \mathrm{s}$ during the fall to flows of $1,538 \mathrm{ft}^{3} / \mathrm{s}$ in the spring (Haring, 2003). Water temperatures remain cold, and river flow is maintained by cold springs and seeps coming from high-altitude snowmelt throughout the summer. However, the White Salmon River was listed in 1998 under Section 3039(d) of the Federal Clean Water Act as not meeting Washington State water-quality standards for fecal coliform after testing was conducted at rkm 2.3 and 19.3. In 2011, results from fecal coliform monitoring at these locations indicated that the White Salmon River met fecal coliform standards at rkm 2.3 (downstream of Condit Dam) and 19.3 (near BZ Corner), but still exceeded fecal coliform standards at rkm 36 (Collyard, 2011). 


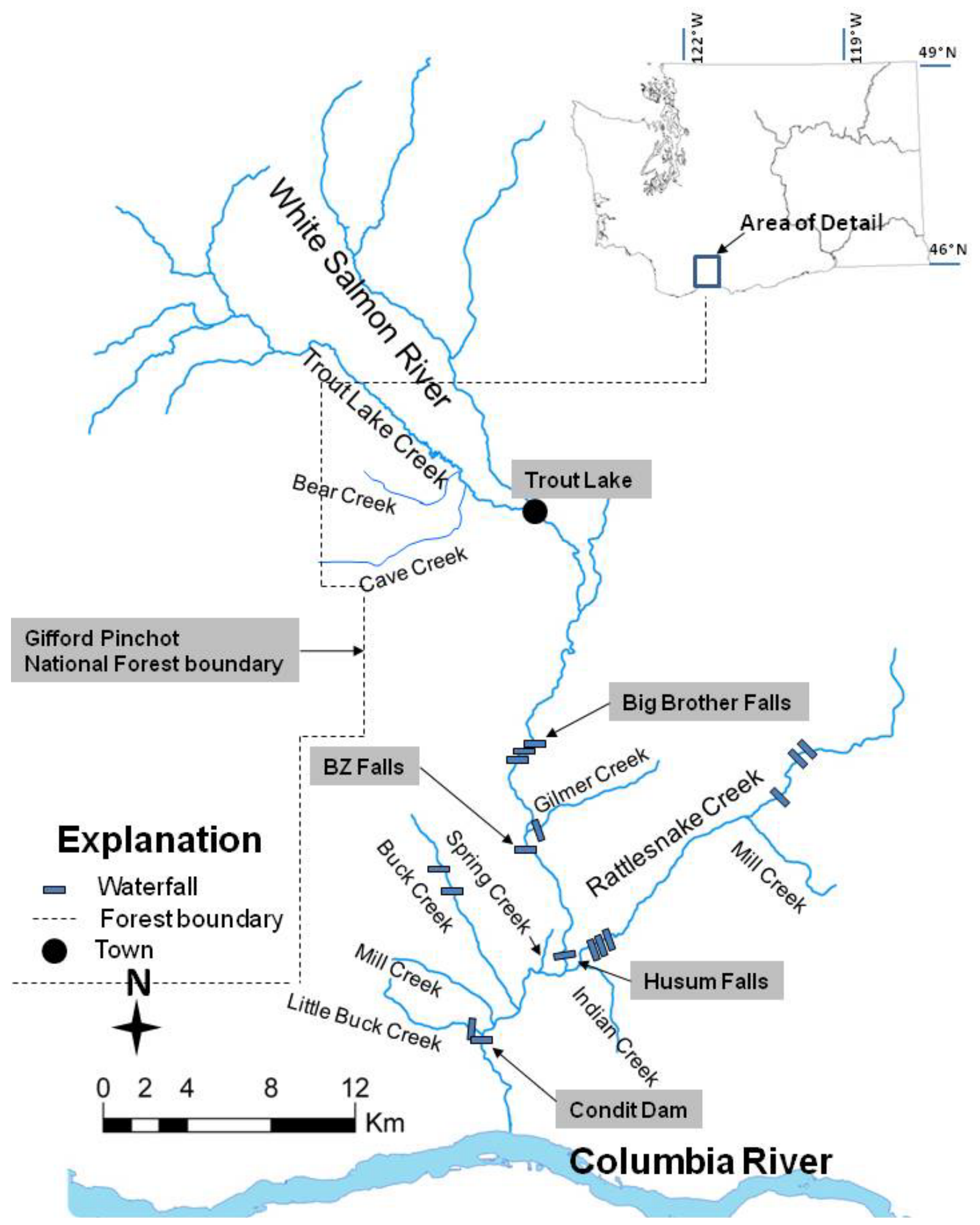

Figure 1. Schematic showing White Salmon River, its main tributaries, U.S. Forest Service boundary, and waterfalls that have potential to be barriers to fish migration, Washington. 
The mainstem White Salmon River from the Columbia River upstream to BZ Falls is for the most part naturally confined through a basalt canyon. All tributaries from rkm 0 to 5 and rkm 12 to 20 are inaccessible to salmonids because of high waterfalls at the tributary mouths (Northwest Power and Conservation Council, 2004, p. 28; Washington Department of Wildlife and others, 1990). There is little complex habitat with floodplain interaction, large woody debris (LWD), backwaters, eddies, or sandbars throughout the entire reach. Condit Dam, at rkm 5.0, was breached in October 2011, and habitat conditions downstream of the dam or in the former Northwestern Lake (up to rkm 8.0) are rapidly changing as the sediment behind the dam redistributes in this part of the drainage basin. Prior to breaching, habitat surveys suggested that there was suitable lamprey habitat upstream and downstream of the dam for spawning and rearing of lamprey (Jolley and others, 2012a). Pacific and western brook lamprey (Lampetra richardsoni) were collected downstream of Condit Dam by deepwater electrofishing (Jolley and others, 2012), backpack electrofishing (Silver, 2010b), and rotary screw trapping (Allen and Connolly, 2011). Western brook lamprey have been found upstream of Condit Dam in the reservoir and mainstem upstream and downstream of Husum Falls (Jolley and others, 2012; B. Allen, U.S. Geological Survey, unpub. data, 2008). Western brook lamprey also have been found in Mill, Buck, Rattlesnake, and Trout Lake Creeks, as detailed later in this report. Because Condit Dam had blocked sediment transport for nearly 100 years, spawning gravel and fine sediment needed for rearing lamprey were limited in the river downstream of the dam (rkm 1 to 5). However, the lowest kilometer of the White Salmon River was inundated by the Bonneville Dam, and this slow velocity reach contained fine sediment for lamprey rearing (85 percent of mean substrate particle size was less than $0.5 \mathrm{~mm}$ with 7.1 percent organic content at lamprey sampling sites) (Jolley and others, 2012b). The sediment that has now been released from upstream of Condit Dam has filled the reach inundated by the Bonneville Dam, and has created a delta at the river mouth. This has increased the water velocity in the lower kilometer and likely reduced juvenile lamprey rearing habitat, at least in the short term. After Condit Dam removal has been completed and sediment from the reservoir stabilizes, Pacific lamprey access to habitat upstream of the dam will be restored, and habitat downstream of the dam should improve.

The tributaries with potential lamprey habitat downstream of rkm 20 (all upstream of Condit Dam) are Little Spring Creek, Little Buck Creek, Mill Creek, Buck Creek (all were tributaries to Northwestern Lake), Rattlesnake Creek and its tributaries (Mill and Indian Creeks), and Spring Creek (tributary to White Salmon River about $2 \mathrm{~km}$ downstream of Husum). Based on bottom contour profiles of Northwestern Lake conducted in 1910, Buck Creek likely would remain accessible to lamprey after the removal of Condit Dam, and at least the lower end of Mill Creek would likely remain accessible. Little Spring and Little Buck Creeks are in the most downstream part of the old reservoir, have very steep hillslopes, and would likely have waterfalls or very steep gradients after dam removal (Allen and Connolly, 2005, app. A). Although lamprey can climb vertical surfaces, the small size of Little Spring and Little Buck Creeks makes their potential use by Pacific lamprey unlikely.

Because of the naturally confined character of this section of the White Salmon River, low habitat complexity, and the general lack of LWD(Normandeau, 2004), suitable larval habitat likely is present but limited.

\section{Mill Creek (rkm 6.4)}

Mill Creek is a river right (all references to tributary confluence direction are made while looking downstream) tributary entering the White Salmon River from the west within the former Northwestern Lake (fig. 1). The likelihood of fish passage into Mill Creek after Condit Dam removal is unknown. The stream is naturally confined by valley topography, has a perched culvert at rkm 0.5 (Plummer and Zuckerman, 2011), and a 1.5-m-high waterfalls at rkm 1 (Haring, 2003). Western brook 
lamprey were documented spawning a few meters upstream of the confluence with the lake (B. Allen, U.S. Geological Survey, unpub. data, 2003). A 1912 bathymetry survey conducted prior to Condit Dam's construction shows contour lines that indicate a clearly defined valley where Mill Creek joins the White Salmon River, and a gradient of approximately 6.9 percent (Allen and Connolly, 2005, app. A). These data suggest that Pacific lamprey should be able to access Mill Creek. However, because of the stream's small size and the existing perched culvert, Pacific lamprey use may be limited.

\section{Buck Creek (rkm 8.0)}

Buck Creek is a river right tributary that enters the White Salmon River from the west (fig. 1). The total area of the drainage basin is $36 \mathrm{~km}^{2}$, approximately 90 percent of which has been owned and managed by Washington Department of Natural Resources since 1921. The drainage basin primarily is forested (with second growth and early successional mixed conifer and deciduous trees), and has steep canyons with incised basalt bedrock channels. Much of the information used here to describe Buck Creek comes from a fish and habitat survey that was conducted by the USGS in 2009 and 2010 (draft report not available for citation at the time of this writing, 2009). During this effort, 15 to 20 western brook lamprey were collected per year in the lower $100 \mathrm{~m}$ using backpack electrofishing during salmonid surveys (B. Allen, U.S. Geological Survey, unpub. data, 2009). The stream was naturally confined, with a single straight channel, a manmade fish barrier (1.1-m-high irrigation diversion) at rkm 3.1, and two natural barriers, one at rkm 5.0 (4.3 $\mathrm{m}$ high) and the other at rkm 6.3 (6 $\mathrm{m}$ high). The gradient from the barrier waterfalls at rkm 6.3 to the confluence with the White Salmon River was 3.6 percent. Just upstream of the natural barrier at rkm 6.3, the City of White Salmon operated a water diversion with a slow-sand water filtration facility for domestic water supply. The irrigation diversion at rkm 3.1 was unscreened and entrainment of lamprey would be likely (Plummer and Zuckerman, 2011). During 2009 and 2010, minimum summer discharge in Buck Creek was $3.3 \mathrm{ft}^{3} / \mathrm{s}$ downstream of the irrigation diversion ( $\mathrm{rkm} 3.1$ ) and $7.7 \mathrm{ft}^{3} / \mathrm{s}$ at its confluence with the White Salmon River. Water temperatures in Buck Creek typically were cold, rarely exceeded $16^{\circ} \mathrm{C}$, and did so only in the lowest reach. Large cobble riffles represented 83 percent of the available habitat overall. Pools, composing 15 percent of the surface area overall, were mostly formed by bedrock with low instream cover and complexity. Instream wood averaged 6 to 10 pieces per $100 \mathrm{~m}, 80$ percent of which was less than $50 \mathrm{~cm}$ in diameter. Rainbow trout was the dominant fish species in all reaches, and the highest abundance of age-0 rainbow trout was in the most downstream reach. Boulders and cobble dominated the stream substrate, with limited gravel available for lamprey spawning and very little braiding or channel complexity that might create habitat containing fine sediment for lamprey rearing.

\section{Spring Creek (rkm 10.6)}

Spring Creek enters the White Salmon River on river right from the west (fig. 1) with relatively high perennial flow and low temperatures. Summer flow volume was estimated to be about $7 \mathrm{ft}^{3} / \mathrm{s}$ (Haring, 2003). A small private dam at rkm 1.2 blocks fish passage and impounds about 1.0 ha of water. There is an additional $0.7 \mathrm{~km}$ of stream channel upstream of the first impoundment to a second small dam and hydroelectric facility near Spring Creek's source (Haring, 2003). The stream upstream of the first dam has beaver activity and abundant fine sediment. Downstream of the first dam, the stream has a gradient of 1.2 percent and a gravel streambed. Riparian vegetation is a second-growth, 50-year-old forest (Haring, 2003). 


\section{Rattlesnake Creek (rkm 12)}

Rattlesnake Creek enters the White Salmon River on river left from the east, and has two perennial tributaries, Indian and Mill Creeks (fig. 1). Indian Creek is a river left tributary entering Rattlesnake Creek at rkm 1.0 and Mill Creek is a river left tributary entering Rattlesnake Creek at rkm 14. Rattlesnake Creek is largely entrenched with little floodplain interaction (Morris, 2005). There are several waterfalls on Rattlesnake Creek that may limit fish distribution. The lowest set of waterfalls, at rkm 2.4, contains three individual drops, with the largest being $3.6 \mathrm{~m}$. The uppermost trout distribution was at a plunge pool beneath a $2.5 \mathrm{~m}$ waterfall at rkm 16.6 (Allen and others, 2006a). The uppermost set of two waterfalls at rkm 17.2 and 17.5 are each more than $22 \mathrm{~m}$ and are complete fish barriers. Indian Creek has a perched culvert less than $100 \mathrm{~m}$ from its confluence with Rattlesnake Creek; however, it is scheduled to be replaced by a bridge in 2012. Rattlesnake Creek discharge ranged from $0.3 \mathrm{ft}^{3} / \mathrm{s}$ in the summer to several hundred cubic feet per second in the winter (Allen and others, 2006a). Streamflows less than $1 \mathrm{ft}^{3} / \mathrm{s}$ were common from July through September. Fish habitat was degraded, with low pool frequency, low quantities of LWD, and high stream temperatures (more than $24^{\circ} \mathrm{C}$ just upstream of the Indian Creek confluence). The dominant substrate in lower Rattlesnake Creek was cobble and boulders (Morris, 2005). Downstream of the lower waterfalls, only occasional localized pockets of suitable spawning gravel were found on the channel margins or behind large obstructions, limiting the number of potential spawning redds that can be constructed (Western Watershed Analysts, 1997). Riparian vegetation along the creek was dominated by alders, with few conifers present (Allen and others, 2006a). Residential development encroached upon the riparian zone at several locations in the lower part of the creek (Haring, 2003). In addition, the county road is located within a few meters of lower Rattlesnake Creek, impairing riparian function in the area that Pacific lamprey are most likely to recolonize.

Land uses within the Rattlesnake Creek subbasin include forest (about 96 percent of area), residential (3 percent), and agriculture (1 percent) (Western Watershed Analysts, 1997). Most residential activity was located in the lower river. The basin was heavily logged by the 1920s-1930s, and by the late 1950s, nearly all forested acres in the basin had been harvested at least once (Haring, 2003). Rattlesnake Creek was listed in 1998 under Section 3039(d) of the Federal Clean Water Act as not meeting Washington State water-quality standards for fecal coliform and temperature (Stampfli, 1994). In 2011, results from fecal coliform monitoring indicated that Rattlesnake Creek still exceeded fecal coliform standards. Onsite sewage systems are one of the suspected sources of fecal coliform pollution, although other possible sources cannot be ruled out completely (Collyard, 2011). Western brook lamprey occasionally were found in lower Rattlesnake Creek by Allen and others (2006a) using backpack electrofishing during salmonid surveys.

\section{White Salmon River Upstream of BZ Falls (rkm 20)}

It is uncertain whether the Pacific lamprey are able to climb the natural barriers and withstand the sustained fast and turbulent flow of the White Salmon River beginning at rkm 20 (BZ Falls, 4.5-5.2 $\mathrm{m}$ high). The river gradient decreases an average of 2 percent from rkm 27 to 20 as it flows through a steep gorge with several waterfalls, including a series of four waterfalls at rkm 26, the largest being 7.6 $\mathrm{m}$ high. The series of waterfalls from rkm 25 to 26 are considered to be a complete block to all salmonid passage at all flows (Bair and others, 2002; Normandeau, 2004). All tributaries between rkm 20 and 26 are inaccessible to salmonids because of high waterfalls at their mouths (Northwest Power and Conservation Council, 2004, p. 28; Washington Department of Wildlife and others, 1990). The White Salmon River between rkm 16 and 35 was considered "regionally significant" because of the volume of water and concentration of waterfalls greater than $3 \mathrm{~m}$ high over a short section of river (Land and 
Water Associates, 1989). If Pacific lamprey are able to ascend this section and several other waterfalls above it, habitat in the mainstem White Salmon River and its primary tributary (Trout Lake Creek) would likely be suitable, as indicated by the presence of western brook lamprey (Silver and others, 2010b).

Overall, the fish habitat from rkm 26 to 50 was rated as moderately impaired in the White Salmon River subbasin plan (Normandeau, 2004). Glacial melt in spring and summer maintain relatively high flow. The habitat was functional and likely capable of supporting lamprey, but key habitat features - such as channel complexity, LWD, riparian function, temperature, fine sediment in spawning gravels, peak flow, and channel stability - were reduced or impaired. The primary causes cited for the impaired habitat were loss of LWD, density of roads $\left(3.8 \mathrm{~km} / \mathrm{km}^{2}\right)$, and clearing of forests, which increased peak flow and sediment delivery (Normandeau, 2004). The U.S. Forest Service (USFS) upper White Salmon River watershed analysis (1998) indicated that stream habitat and drainage basin processes for the area upstream of rkm 50 are approaching properly functioning conditions (as defined by Pritchard and others, 1998). From its headwaters on Mount Adams, the river has cliffs, waterfalls, and deeply incised canyons, declining more than 1,524 $\mathrm{m}$ in altitude before it reaches Trout Lake near rkm 42, with a gradient change of 4 percent between rkm 56 and 48 (National Marine Fisheries Service, 2008). Many springs enter the river between rkm 28 and 31, with 67 springs and 20 tributaries for a total of $700 \mathrm{ft}^{3} / \mathrm{s}$, or about 50 percent of the river's average low flow (Haring, 2003).

A number of small tributaries enter the river upstream of the USFS boundary at rkm 50. Trout Lake Creek enters at rkm 42. Downstream of the Trout Lake Creek confluence, the river quickly narrows into a series of box canyons with intermittent streams and springs joining the mainstem (Water Professional Network and Mark Yinger Associates, 2002). Upstream of the Trout Lake Creek confluence, minimal water-quality concerns have been identified, water temperatures are cold, with an annual average maximum of $11^{\circ} \mathrm{C}$ over 15 years (U.S. Forest Service, 1998), and Washington State water-quality standards are not known to have been exceeded (Haring, 2003). Downstream of the Trout Lake Creek confluence, water temperatures and fecal coliform concentrations have exceeded State water-quality standards (Haring, 2003).

In the Trout Lake Valley, few of the irrigation diversions or pumps are screened to prevent juvenile lamprey impingement or entrainment. Some riparian areas downstream of USFS land are in need of restoration and LWD is limited (Normandeau, 2004). This lack of LWD has increased flow energy, resulting in loss of already limited gravel, increased bank erosion, and further channel incision. This has reduced floodplain connectivity, which was already naturally limited (Haring, 2003; Normandeau, 2004).

\section{Gilmer Creek (rkm 20.4)}

The Gilmer Creek basin drains $30 \mathrm{~km}^{2}$ (Hennelly and others, 1994) and is a river left tributary entering the White Salmon River from the east (fig. 1). Pacific lamprey passage from the White Salmon River into Gilmer Creek may be limited by passage over BZ Falls and a $6 \mathrm{~m}$ waterfall at the mouth of Gilmer Creek (Hennelly and others, 1994). Rainbow trout are present in Gilmer Creek and are thought to be a naturally spawning and persistent stock. Gilmer Creek flows through two canyon sections and two meadows; soils in the meadows are erodible sandy silts (Hennelly and others, 1994). Sediment deposition from poor land-use practices was identified as a concern. One of the surveyed reaches had 77 percent actively eroding bank, and another reach had 27 percent actively eroding bank (Haring, 2003). Irrigation water was pumped into Gilmer Creek from the White Salmon River to provide water for orchard irrigation during the summer. In summer, 77 percent of the length of surface flow in Gilmer Creek was water from a diversion that was taken from the White Salmon River (Haring, 2003). 
Land-use activities in the Gilmer Creek subbasin include orchards in the lower subbasin and a livestock operation in the upper subbasin. Seasonal grazing of livestock also occurs in the forested areas of Gilmer Creek during the dry season. Animals have unrestricted access to Gilmer Creek at multiple locations during these times. Nitrate concentrations in Gilmer Creek were as high as $8.2 \mathrm{mg} / \mathrm{L}$ and were much higher than in any other stream in the White Salmon River basin (next highest nitrate concentrations were $0.3 \mathrm{mg} / \mathrm{L}$ in Rattlesnake Creek) (White and Cochrane, 2005). Gilmer Creek was listed in 1998 under Section 3039(d) of the Federal Clean Water Act as not meeting Washington State water-quality standards for temperature and fecal coliform. In 2011, results from fecal coliform monitoring indicated that Gilmer Creek was still exceeding fecal coliform standards (Collyard, 2011).

\section{Cave and Bear Creeks (rkm 41)}

Cave Creek is a river right tributary that enters the White Salmon River just downstream of the Trout Lake Creek confluence; Bear Creek presently flows through the field adjacent to the town of Trout Lake, mile marker 21.1 on SR 141, and joins Cave Creek just before the SR 141 Bridge, mile marker 21.0 (U.S. Forest Service, 1997a). At the time of the USFS watershed analysis, there was no surface-water connection between Cave Creek and the White Salmon River for at least several months of the year (U.S. Forest Service, 1997a). The basin area totals $135 \mathrm{~km}^{2}$, of which 67 percent is located on Federal land in the Gifford Pinchot National Forest (U.S. Forest Service, 1997a). The highest water temperature measured in Cave Creek by USFS was $17^{\circ} \mathrm{C}$ (Haring, 2003). Cave Creek supports resident salmonids, but Bear Creek is dry most of the time and is not known to support resident salmonids. There are several irrigation diversions that originate in Cave and Bear Creeks, but the extent and routing of all diversions has not been fully assessed (Haring, 2003). The screening status of the irrigation diversions has not been assessed, but most are thought to be unscreened (Haring, 2003). Because of the stream diversions, channelization, and realignment that have occurred in Trout Lake Valley since the late 1800s, it was difficult to determine the original locations of streams in the valley (U.S. Forest Service, 1997). Spawning habitat is lacking in Cave Creek because of a lack of gravel and high silt loads (U.S. Forest Service, 1997). Silt accumulations of up to $1 \mathrm{ft}$ in depth were found in lower Cave Creek in 1989.

\section{Trout Lake Creek (rkm 42)}

Trout Lake Creek is a river right tributary of the White Salmon River that drains about $194 \mathrm{~km}^{2}$ of the basin (fig. 1). The hydrology is driven by snowmelt and peak flows that typically are rain on snow events. The drainage basin includes $80 \mathrm{~km}$ of fish-bearing streams. The hydrology of the lower basin reflects past activities to develop irrigation ditch systems and to relocate stream channels to accommodate land uses or divert water to points of use (U.S. Forest Service, 1996). None of the irrigation diversions into ditches in Trout Lake Creek have screening to prevent lamprey entrainment (Haring, 2003). The "lake" in the Trout Lake Creek basin is currently transitioning to a marsh or wetland and would likely provide good rearing habitat for Pacific lamprey, provided the adult lamprey can navigate the mainstem White Salmon River to access Trout Lake Creek. Western brook lamprey have been found in the lower Trout Lake Creek (Silver and others, 2010b), indicating that the habitat would likely be suitable for Pacific lamprey. Watershed analysis of Trout Lake Creek found LWD lacking, and water temperatures and fecal coliform exceeded State water-quality standards (U.S. Forest Service, 1996). Trout Lake Creek and Trout Lake Ditch were listed in 1998 under Section 3039(d) of the Federal Clean Water Act as not meeting Washington State water-quality standards for fecal coliform and temperature. In 2011, results from fecal coliform monitoring indicated that Trout Lake Creek and Trout Lake Ditch were currently meeting fecal coliform standards (Collyard, 2011). 


\section{Annotated Bibliography}

Allen, M.B., and Connolly, P.J., 2005, Assessment of the White Salmon watershed using the ecosystem diagnosis and treatment model: U.S. Geological Survey, Columbia River Research Laboratory, Cook, Washington, $55 \mathrm{p}$.

Keywords: habitat conditions, salmonid population modeling, limiting factors, restoration, life history Notes: Assessment of the White Salmon River basin through Ecosystem Diagnosis and Treatment (EDT) habitat analyses along each reach of the White Salmon River downstream of rkm 26. Relative importance of each geographic area in the basin is ranked to prioritize restoration efforts. The report includes descriptions of salmonid life histories and historical distributions of salmonids in the White Salmon River basin. Appendix A of this report summarizes the data used to evaluate riparian and instream habitat conditions and data sources used in each reach for this analysis.

Allen, M.B., Connolly, P.J., Jezorek, I.G., Munz, C., and Charrier, J.C., 2006a, Assess current and potential salmonid production in Rattlesnake Creek in association with restoration efforts: U.S. Geological Survey 2004-2005 Annual Report, Project No. 200102500, BPA Report DOE/BP00005068-4, 101 p.

Keywords: fish populations, fish distribution, habitat conditions, streamflow, water temperature, waterfalls

Notes: This project was designed to document existing habitat conditions and fish populations within the Rattlesnake Creek basin. Project scientists surveyed water temperatures, stream discharge, stream habitat, and riparian conditions, and assessed the abundance of the fish populations, fish species composition, genetics, diseases, and distribution, including movements of Passive Integrated Transponder (PIT)-tagged salmonids through an instream PIT tag detection system. Western brook lamprey were found a few hundred meters upstream of the confluence with the White Salmon River.

Allen, M.B., Connolly P.J., Munz C., and Charrier J.C., 2006b, Assess current and potential salmonid production in Rattlesnake Creek in association with restoration efforts: U.S. Geological Survey 20032004 Annual Report, Project No. 200102500, BPA Report DOE/BP- 00005068-3, 128 p.

Keywords: fish populations, habitat conditions, streamflow, water temperature, waterfalls

Notes: This project was designed to document existing habitat conditions and fish populations within the Rattlesnake Creek basin. Project scientists surveyed water temperatures, stream discharge, stream habitat, LWD, and riparian conditions, and assessed the status of the fish populations, fish species composition, genetics, diseases, and distribution, including movements of PIT-tagged salmonids. Western brook lamprey were found a few hundred meters upstream of the confluence with the White Salmon River.

Allen, M.B., and Connolly, P.J., 2011, Composition and relative abundance of fish species in the lower White Salmon River, Washington, prior to the removal of Condit Dam: U.S. Geological Survey Open-File Report 2011-1087, 32 p.

Keywords: rotary screw trap, fish species composition, lamprey counts, capture efficiency Notes: An assessment of the composition and relative abundance of fishes downstream of Condit Dam in the Lower White Salmon River prior to the removal of Condit Dam. Results from rotary screw trapping and backpack electrofishing include the number of lamprey captured during the sampling season. 
Althauser, Don, 1982, Big White Salmon River, summary of physical survey: Draft report, White Salmon, Washington.

Keywords: water diversion, fish barriers, water use, fish habitat, spawning areas, streambeds, tributaries

Notes: A report based on a physical survey of the river done in 1982. It includes the location and description of water diversions in the White Salmon River and its tributaries. It also describes the streambed characteristics and gradient as well as major barriers to fish migration.

Bair, Brian, Grover, Dean, and Powers, Paul, 2002, Effects of the proposed Condit Dam removal on fish populations and habitat in the White Salmon Wild and Scenic River: USDA Forest Service report, Carson, Washington.

Keywords: Condit Dam removal, ecology, lamprey habitat, steelhead, water quality, productivity, rainbow trout, fish populations

Notes: A study examining the habitat impacts of removal of the Condit Dam and how it will affect fish population and reproduction. It specifically mentions the quantity of additional habitat for lamprey if the dam is removed (an additional $20 \mathrm{~km}$, up to rkm 26).

Bechtel Civil and Minerals, Inc., 1981a, Proposal for services-White Salmon River hydroelectric project: Prepared for Public Utility District No. 1 of Klickitat County, Washington.

Keywords: hydroelectric projects, geology, hydrology, reservoir, dam proposals, streamflow Notes: This is a feasibility study by Bechtel Civil and Minerals, Inc. on a proposed series of dams and diversions to produce hydroelectricity on the White Salmon River. It is based on plans developed in the previous decades, which placed an emphasis on hydropower development. It includes a map of gaging stations along the river and a table of historical streamflow data.

Bechtel Civil and Minerals, Inc., 1981b, White Salmon River project phase I conceptual planning report: Prepared for Public Utility District No. 1 of Klickitat County, Washington, 167 p. Keywords: Hydroelectric projects, storage alternatives, environmental analysis Notes: A preliminary evaluation of a proposed hydroelectric project on the White Salmon River near rkm 34. The report addresses hydrology and energy studies in addition to environmental and economic analyses of several hydroelectric project alternatives. Monthly flow data from several locations along the White Salmon River are included.

Berkowitz, Laurie, 1999, White Salmon River watershed enhancement project water quality screening program report: Northwest Service Academy/AmeriCorps, Trout Lake, Washington and Underwood Conservation District, White Salmon, Washington.

Keywords: water quality, outreach, groundwater, coliform bacteria, maps Notes: This report is based on analysis of 59 samples of well and spring water in the White Salmon River basin. Well owners were encouraged to provide samples through a local outreach program and were provided materials on protecting water quality. 
Boyd, K.C., 2003, Habitat level 1 technical assessment - Water Resource Inventory Area (WRIA) 29: Prepared for WRIA 29 Planning Unit, Skamania County Department of Planning and Community Development, Stevenson, Washington, 75 p.

Keywords: fish habitat, habitat conditions, management, restoration, limiting factors, land use, tributaries

Notes: The Washington State Department of Ecology water quality rules and priorities were used to review each subbasin and tributary in the drainage basin with respect to salmonid habitat. The report has an extensive bibliography.

Bureau of Reclamation, 1974, White Salmon division-Columbia north side project: Appraisal report, Spokane, Washington, $146 \mathrm{p}$.

Keywords: dam proposals, water diversion, water use, comments, streamflow, human impacts, nuclear powerstation, maps

Notes: An appraisal of five potential alternatives for the White Salmon River. The report concentrates on human use of natural resources, and most alternatives propose removing Condit Dam but replacing it with a series of dams and diversions on upstream tributaries. One use for the diverted water was as cooling water for a proposed nuclear power plant.

Bureau of Reclamation, 1993, Water quality data: Water quality data, Boise, Idaho, 9 p.

Keywords: water quality, raw data, streamflow, water monitoring, water analysis

Notes: This is water-quality data from the U.S. Environmental Protection Agency and includes data from Rattlesnake Creek and the White Salmon River. The dates covered range from 1972 to 1975.

Collyard, Scott, 2011, White Salmon River watershed fecal coliform bacteria attainment monitoring study: Washington State Department of Ecology, Olympia, Washington, Publication No. 11-03-046, $74 \mathrm{p}$.

Keywords: coliform bacteria, water quality, land use

Notes: Three segments of the White Salmon River and four of its tributaries (Trout Lake Creek Ditch and Rattlesnake, Gilmer, and Trout Lake Creeks) were listed in 1998 under section 303(d) of the Clean Water Act as not meeting State water-quality standards for fecal coliform bacteria. This report summarizes data collected in 2009 to determine if these waters complied. Results indicated that the White Salmon River at rkm 36 and Gilmer and Rattlesnake Creeks still exceeded standards. The other sites that were tested met State water-quality standards. Potential sources of coliform bacteria, such as cattle and failed septic systems, were identified in this report.

Columbia Basin Fish and Wildlife Authority, 1995, Joint agency/tribal plan for ecosystem restoration of the White Salmon River: Columbia Basin Fish and Wildlife Authority, draft report, Portland, Oregon. Keywords: restoration, Condit Dam removal, fish habitat, fish populations, water quality, fish management, lamprey restoration.

Notes: This plan examines the potential for river ecosystem restoration under two alternatives removal or retention of Condit Dam. It looks at the impact on anadromous fish populations and habitat, concluding that only under the dam removal proposal could lamprey stocks improve. 
Columbia River Basin Lamprey Technical Workgroup, 2011, Translocating adult Pacific Lamprey within the Columbia River basin-State of the science: Prepared for Columbia Basin Fish and Wildlife Authority, Portland, Oregon, 38 p.

Keywords: Pacific Lamprey, lamprey restoration, lamprey translocation, lamprey habitat. Notes: The report examines the current and traditional Tribal use of Pacific lamprey, population trends, and restoration efforts. It uses two case studies of adult lamprey translocation efforts by the Umatilla and Nez Perce Tribes that show some success at reintroduction of lamprey to rivers where they had been absent. There is a section on risks and benefits of translocation projects and an extensive bibliography.

Connolly, P.J., 2002, Assess current and potential salmonid production in Rattlesnake Creek associated with restoration efforts: U.S. Geological Survey, Columbia River Research Laboratory, report prepared for Bonneville Power Administration, Portland, Oregon, Project No. 200102500, BPA Report DOE/BP-00005068-1, 188 p.

Keywords: streamflow, water temperature, fish species composition, habitat conditions, disease profiling

Notes: This is an assessment that documents the current habitat conditions and fish populations in Rattlesnake Creek to identify and prioritize restoration efforts. The paper includes maps, water-quality data, graphs, and the presence or absence of fish species by reach.

Connolly, P.J., Sharpe, C.S., and Sauter, Sally, 2001, Evaluate status of coastal cutthroat trout in the Columbia River Basin above Bonneville Dam: Prepared for Bonneville Power Administration, Portland, Oregon, Project Number: 2001-007-00, BPA Report DOE/BP-00005678, 87 p. Keywords: Oncorhyncus clarki, Bonneville and The Dalles Dams, historical distribution, hybridization

Notes: This is a summary of the current status and distribution of costal cutthroat trout populations in the Gorge Province, including the White Salmon River and tributaries.

Crump, Robert, Coffin, Bengt, Claggett, Sally, Scott, Betsy, Mendez-Treneman, Rolando, 1995, Upper White Salmon River watershed analysis: U.S. Forest Service, Gifford Pinchot National Forest, Mount Adams Ranger District, 45 p.

Keywords: habitat conditions, water quality, historical impact mechanisms

Notes: Assessment of current conditions within the Upper White Salmon River basin. Analysis includes current habitat conditions such as turbidity, prevalence of fecal coliform, stream survey data, channel types, and fragmentation.

Ehinger, Bill, 1995, Water quality data for White Salmon River and Gilmer Creek: Washington State Department of Ecology, Olympia, Washington, 3 p.

Keywords: water quality, raw data, coliform bacteria, water temperature, water analysis

Notes: Raw data from the State of Washington on water quality in the White Salmon River and Gilmer Creek from October 1994 to September 1995. 
Encon Corporation, 1973, Water quality management plan Mid-Columbia Basin (Washington) and water resource inventory areas (WRIA) 29-30-31: Revised draft report prepared for Klickitat County Regional Planning Council, Goldendale, Washington, 194 p.

Keywords: water quality, wastewater treatment, water resource management, land use Notes: Proposed water-quality management plan designed to meet projected increases in demand for water resources within WRIAs 29 (Wind-White Salmon), 30 (Klickitat), and 31(Rock-Glade). The report includes numerous maps and water-quality tables.

Federal Energy Regulatory Commission, 1996, Condit Hydroelectric Project final environmental impact statement: FERC Project No. 2342-005, Washington, D.C., 708 p.

Keywords: improvement projects, resource analysis

Notes: Environmental impact statement associated with PacifiCorp's request for relicensing of the Condit Hydroelectric Project. The assessment includes some information on non-salmonid use of the White Salmon River.

Federal Energy Regulatory Commission, 2002, Final supplemental, final environmental impact statement, Condit Hydroelectric Project, Washington: FERC Project No. 2342, Washington, D.C., 309 p.

Keywords: resource analysis, Condit Dam removal

Notes: A thorough assessment of the environmental impacts associated with the removal of Condit Dam. The impacts on various resources are evaluated. Maps, data tables, and figures included.

G\&G Associates, 2004, Condit hydroelectric project removal sediment behavior analysis report: Prepared for PacifiCorp, White Salmon, Washington.

Keywords: sediment, Condit Dam removal, water quality, fish habitat

Notes: A comprehensive report investigating the behavior of sediment remaining after the draining of Northwestern Lake caused by the removal of Condit Dam. It examines the hydrology and erosion of these sediments and the long- and short-term effects of this higher sediment load on downstream ecology.

Golder Associates Inc., and Entrix Inc., 2001, An interim strategy to protect and restore salmonid habitat in the Klickitat, White Salmon and Little White Salmon River basins: Draft report prepared for the Klickitat County Citizens Review Committee, Goldendale, Washington, 80 p.

Keywords: fish habitat, restoration

Notes: This paper is an analysis of current habitat conditions for salmonids in each river basin. The potential of restoration projects is scored based on their impact on specific species. It divides the basins into specific watersheds and recommends priority enhancements for each that will improve habitat.

Hallock, Dave, Ehinger, William, and Hopkins, Brad, 1998, River and stream ambient monitoring report for water year 1996 - Final report: Washington State Department of Ecology, Olympia, Washington, $234 \mathrm{p}$.

Keywords: water quality, water temperature, Rattlesnake Creek

Notes: Results from monthly water quality tests in rivers and streams throughout Washington State. Appendixes include raw data. 
Haring, Donald, 2003, White Salmon River watershed addendum to Wind / White Salmon water resource inventory area 29 salmonid limiting factor analysis (originally issued July 1999): Washington Conservation Commission, Olympia, Washington, 98 p.

Keywords: fish habitat, limiting factors, management, water quality, streambeds, tributaries, restoration

Notes: Analysis of salmonid habitat in the White Salmon River basin, basin descriptions, and key limiting factors for salmon in the mainstem and major tributaries. Document includes life history information on key salmon and trout species and impacts of human activities on their habitats.

Harza Engineering Company and Nuclear Services Corporation, 1974, Draft-appraisal report of the Northside Development Basic Project: Prepared for the Mid-Columbia Economic Development District, The Dalles, Oregon, 244 p.

Keywords: streamflow, nuclear powerstation, irrigation, fish barriers, reservoir

Notes: The Northside Development Basic Project was first proposed in 1967 in an effort to bolster the economic development of Klickitat and Skamania Counties. This report evaluates several project plans based on the geology, hydrology, and cultural and environmental characteristics of the area. Several dam projects are proposed along the White Salmon River and Rattlesnake Creek.

Hennelly, Leslie, and Stampfli, Steve, 1992, Stream/river corridor vegetation survey-raw data sheets for White Salmon River basin assessment and watershed enhancement plan: Underwood Conservation District, White Salmon, Washington, and U.S. Forest Service.

Keywords: vegetation, tributaries, land use, raw data, canopy cover, stream enhancement, Rattlesnake Creek

Notes: Raw data from a riparian corridor vegetation survey conducted in 1992 . The document covers Rattlesnake Creek and other tributaries and includes comments on land use with suggestions for possible enhancements.

Hennelly, Leslie, Delaere, Steve, and Jacobson, Susanne, 1992, Riparian corridor assessment surveyraw data sheets for White Salmon River basin assessment and watershed enhancement plan: Underwood Conservation District, White Salmon, Washington, and U.S. Forest Service, 114 p. Keywords: water quality, water temperature, raw data, tributaries, land use, Rattlesnake Creek Notes: Raw data from a riparian corridor assessment done in 1992. Document includes data from tributaries and comments on land use adjacent to the creeks.

Hennelly, Leslie, Delaere, Steve, and Jacobson, Susanne, 1994, White Salmon River stream survey report: Prepared for Underwood Conservation District, White Salmon, Washington, 50 p. Keywords: tributaries, water quality, streambeds, streamflow, gradient, habitat conditions, fish habitat, ecology, hydrology

Notes: A survey of the White Salmon River and its tributaries divided into reaches beginning at the mouth. Document includes information on streambed, gradient, vegetation, springs, and potential enhancements to improve water quality and fish habitat. 
Hidaka, F.T., and Walters, K.L., 1967, Water resources in the White Salmon area: Report excerpt and U.S. Geological Survey memorandum, 22 p.

Keywords: hydrology, streamflow, ground water, geology, water use

Notes: This document deals mostly with water supply and water use for the area but also includes low-flow records for the White Salmon River based on the preceding 9-year period.

Joint Fishery Party Intervenors, 1995, Joint agency/Tribal plan for ecosystem restoration of the White Salmon River: Columbia Basin Fish and Wildlife Authority, Joint Fishery Party Intervenors in FERC \#2342 report, Portland, Oregon, 26 p.

Keywords: restoration, Condit Dam removal, fish habitat, fish populations, water quality, fish management, lamprey restoration

Notes: This plan examines the potential for river ecosystem restoration under two alternatives removal or retention of Condit Dam. It looks at the impact on anadromous fish populations and habitat and also concludes that only under the dam removal proposal could lamprey stocks improve.

Jolley, J.C., Silver, G.S., and Whitesel, T.A., 2012a, Occurrence, detection, and habitat use of larval lamprey in the White Salmon River Basin pre-Condit Dam removal: 2011 annual report, U.S. Fish and Wildlife Service, Columbia River Fisheries Program Office, Vancouver, Washington, $21 \mathrm{p}$. Keywords: lamprey occupancy, lamprey habitat, baseline data, deepwater sampling, tributaries, population sampling

Notes: This work documents the presence or absence of larval lamprey throughout the lower White Salmon River (downstream of Condit Dam), as well as the lower Wind and Klickitat Rivers, using a randomized, spatially balanced approach. Sampling occurred upstream of the Highway 14 bridge in the inundated part of each river. Pacific and western brook lamprey were found in the Wind (11 of 34 quadrats) and White Salmon (10 of 34 quadrats) Rivers. Only Pacific lamprey were found in the mouth of the Klickitat River (9 of 34 quadrats). Western brook lamprey also were found in supplemental efforts and were abundant in Northwestern Lake (as it was drawn down for removal) and in the newly deposited sediment from the lake after dam breaching in October 2011. Sediment particle size of samples and lamprey length frequencies are provided in this report.

Jolley, J.C., Silver, G.S., and Whitesel, T.A., 2012b, Occurrence, detection, and habitat use of larval lamprey in Columbia River mainstem environments-Bonneville tailwater and tributary mouths: 2011 annual report, U.S. Fish and Wildlife Service, Columbia River Fisheries Program Office, Vancouver, Washington, $25 \mathrm{p}$.

Keywords: lamprey occupancy, lamprey habitat, baseline data, deepwater sampling, tributaries, population sampling

Notes: Surveys of the Bonneville tailwater and the inundated portions of the Hood, Wind, Klickitat, and White Salmon Rivers were conducted for Pacific and western brook lamprey populations using a deepwater electrofisher with suction. One western brook lamprey was found in the Columbia River 28 $\mathrm{km}$ downstream of Bonneville Dam in 1 of the 32 quadrats sampled. Larval lamprey were also found at the mouth of the Hood ( 2 of 34 quadrats) and Wind (10 of 34 quadrats) Rivers, but not at the mouth of the Klickitat or White Salmon Rivers. The surveys found very little suitable habitat at the mouth of the White Salmon River. The area was dominated by deep water, swift flows, and bedrock or coarse substrate. The report provides sediment particle size of samples and lamprey length frequencies. 
Kennedy/Jenks Consultants, 2003, Klickitat County Energy Overlay, draft environmental impact statement: Prepared for Klickitat County, Goldendale, Washington, by Kennedy/Jenks Consultants, 026051.11, Portland, Oregon, 289 p.

Keywords: energy development, land use, natural resources, mitigation, infrastructure Notes: This is an investigation of energy development projects within Klickitat County-their feasibility, site selection, environmental impacts, and proposed mitigation.

Land and Water Associates, 1989, A comparative evaluation of the geologic and hydrologic resource values on the Klickitat and White Salmon Rivers: Final report to USDA Forest Service, Hood River, Oregon, $22 \mathrm{p}$.

Keywords: geology, hydrology, Wild and Scenic Rivers, springs, maps, streamflow, waterfalls Notes: A description of the geologic and hydrologic features of the White Salmon and Klickitat Rivers. This report is part of a larger study for designation of more river sections under the Wild and Scenic Rivers Act. It includes descriptions and maps of the rivers with emphasis on the relative rarity of hydrologic and geologic features of each.

Lane and Lane Associates with Nash, Douglas, 1981, The White Salmon River Indian Fisheries and Condit Dam: Report for the Bureau of Indian Affairs, Portland, Oregon, 215 p.

Keywords: historical Tribal lands, treaty rights, Tribal affiliations, Tribal languages, historical salmon runs, oral history, Tribal fishing grounds, land use, ethnography, Tribal commerce, Tribal fishing methods

Notes: This report has an extensive ethnography of the respective tribes throughout the Columbia River region and includes information on traditional fishing grounds and methods. It includes records of statements by elders regarding traditional fishing grounds and the size of historical salmon runs. There is a timeline of treaty rights rulings from the signing of the treaties up through the Boldt decision.

LeMier, E.H., and Smith, W.E., 1955, Biological appraisal of the Big White Salmon River: U.S. Fish and Wildlife Service Report, Washington, D.C., 10 p.

Keywords: tributaries, streambeds, fish barriers, maps, historical water quality, land use

Notes: This report is based on a survey of the White Salmon River and its tributaries conducted in summer 1955. It includes several maps showing natural and manmade fish barriers on the river at the time.

Lichatowich, Jim, 1994, Review of salmon and steelhead restoration above Condit Dam in the White Salmon River, Washington: Report prepared by Alder Fork Consulting for PacifiCorp, Portland, Oregon, $86 \mathrm{p}$.

Keywords: historical salmon runs, ethnography, salmon potential, Condit Dam removal, fish habitat, fish management, restoration, recommendations, tributaries

Notes: A review of the historical and current evidence of salmon runs and productivity in the White Salmon River basin. The document includes estimates of the historical abundance of salmonids from both government agencies and local and Tribal elders. A comparison of two papers concerning the potential for salmonid productivity is included (Washington Department of Fisheries, 1989; Chapman, 1990). The paper contrasts the spawning habitat conditions and fish productivity estimates for each reach of the river and its tributaries quoting text that was used in each productivity assessment. 
Matthews, J.L., 1992, Eastern Washington stream temperatures and variables influencing them: Yakima Indian Nation Natural Resources Division Timber, Fish and Wildlife Program, Toppenish, Washington, $18 \mathrm{p}$.

Keywords: water temperature, canopy cover, air temperature, groundwater Notes: Temperatures in the White Salmon River and other drainage basins were monitored during summers 1990 and 1991 to assess the influence of several environmental factors on stream temperature. These baseline data were used to identify streams that were likely to exceed Washington State water temperature criteria for salmonids. Water temperature and site condition data are provided.

Morris, G.D., 2003, Assess current and potential salmonid production in Rattlesnake Creek associated with restoration efforts: Report prepared by Yakama Nation for the Bonneville Power Administration, BPA project ID No. 21009, Portland, Oregon, 51 p.

Keywords: stream condition inventories (SCI), sediment, fish habitat, streamflow, water quality Notes: Survey report of water quality, fish populations, habitat conditions, and riparian health of Rattlesnake Creek and its tributaries. Results provide baseline data of various environmental factors intended to guide restoration efforts following the removal of Condit Dam.

Morris, G.D., 2004, Assess current and potential salmonid production in Rattlesnake Creek associated with restoration efforts: Report prepared by Yakama Nation for the Bonneville Power Administration, BPA project ID No. 21009, Portland, Oregon, 64 p.

Keywords: Indian Creek, Husum, stream condition inventories (SCI)

Notes: Similar to Morris, 2003, this report includes the completed stream condition inventory for Indian Creek and the headwaters of Rattlesnake Creek. Appendixes include maps, photographs, ambient and water temperature records, precipitation, and water quality.

Morris, G.D., 2005, Assess current and potential salmonid production in Rattlesnake Creek associated with restoration efforts: Report prepared by Yakama Nation for Bonneville Power Administration, BPA project ID No.17940, Portland, Oregon, 82 p.

Keywords: Major Creek, Mill Creek, water temperature, precipitation, macroinvertebrate, water quality

Notes: Similar to Morris $(2003,2005)$, this report provides additional information concerning riparian surveys in Rattlesnake Creek from 2004 to 2005. Appendixes include photographs, ambient and water temperature records, precipitation records, water-quality records, and the results of macroinvertebrate surveys. 
National Marine Fisheries Service, 2006, Biological Opinion and Magnuson-Stevens Fishery Conservation and Management Act consultation-Interim operation, decommissioning, and removal of the Condit Hydroelectric Project FERC No. 2342, Skamania and Klickitat Counties, Washington: Endangered Species Act Section 7 Consultation, NMFS Log No. 2002/00977,Seattle, Washington, $102 \mathrm{p}$.

Keywords: endangered species, fish habitat, fish populations, Condit Dam removal, critical habitat, limiting factors, erosion, recommendations

Notes: An assessment of how the proposed removal of Condit Dam will affect salmonids listed under the Federal Endangered Species Act. The document examines critical habitat and how dam removal will affect each species. Long-, mid-, and short-term effects of sediment resulting from dam removal on the lower White Salmon river ecosystem are examined.

National Marine Fisheries Service, 2008, ESA recovery plan for the White Salmon River population of Middle Columbia River steelhead: National Marine Fisheries Service Northwest Region, Seattle, Washington, $118 \mathrm{p}$.

Keywords: distinct population segment, genetic diversity, summer and winter steelhead, viability criteria

Notes: Steelhead have been functionally extirpated from the White Salmon River. This recovery plan details the requirements for reestablishing a viable wild steelhead population within the White Salmon River. It discusses current ecosystem conditions, limiting factors and threats, and recovery strategies. The report includes data regarding habitat changes, life history assessments, and harvest rates relating to steelhead in the White Salmon River.

National Oceanic and Atmospheric Administration, 2008, Middle Columbia River steelhead proposed recovery plan-Washington Gorge Management Unit summary: Portland, Oregon, 2 p.

Keywords: endangered species, viability criteria, Major Population Groups (MPGs)

Notes: A plan that outlines the current status, goals, and recovery strategies for salmon and steelhead in the Middle Columbia River and tributaries.

Normandeau Associates, 2004, Draft Lower Mid-Columbia Mainstem Subbasin plan, includes Rock Creek, Washington: Prepared for the Northwest Power and Conservation Council, Portland, Oregon, $404 \mathrm{p}$.

Keywords: habitat conditions, ecology, subbasin plan, endangered species, limiting factors, Pacific lamprey, management plan

Notes: This is a comprehensive management plan to improve habitat for endangered species by looking at overall ecosystem health. It uses key representative species for each habitat type to gauge overall ecosystem health. It includes specific sections on Pacific lamprey and includes management recommendations to aid in their recovery. 
Normandeau Associates, 2004, White Salmon Subbasin plan: Prepared for the Northwest Power and Conservation Council, Portland, Oregon, 248 p.

Keywords: habitat conditions, subbasin plan, focal species, restoration, Chinook, steelhead, coho, management plan

Notes: A report of technical assessments, inventory analyses, and management plans for biological resources of the White Salmon River drainage basin. The effects of drainage basin processes on salmonid productivity are described, along with strategies for salmonid conservation and restoration.

Plummer, Emily, and Zuckerman, Adrianne, 2011, White Salmon River watershed anadromous fish passage inventory 2009-2011 survey report: Underwood Conservation District, White Salmon, Washington, $53 \mathrm{p}$.

Keywords: Fish barriers, unscreened diversions, habitat conditions

Notes: This report details the findings of a fish passage inventory of all potentially anadromous fish habitat in the White Salmon River basin using Washington Department of Fish and Wildlife barrier assessment and water diversion screening protocols. It also includes stream habitat characteristics, limiting factors, potential restoration projects, and appendixes with raw data and aerial photographs.

Rawding, Dan, 2000, White Salmon River subbasin summary: Draft report prepared for the Northwest Power Planning Council, Washington Department of Fish and Wildlife, Olympia, Washington, 28 p. Keywords: Fish habitat, endangered species, management, land use, hydrology, water quality, limiting factors, restoration

Notes: A summary of fish and wildlife habitat in the watershed with an emphasis on threatened and endangered species. It includes resource goals and objectives of regional stakeholders such as the Yakima Nation and other State and local entities.

Silver, G.S., Jolley, J.C., and Whitesel, T.A., 2010a, White Salmon River Basin-Lamprey Project 2007-2009 annual report: U.S. Fish and Wildlife Service, Columbia River Fisheries Program Office, Vancouver, Washington, $23 \mathrm{p}$.

Keywords: lamprey population, lamprey habitat, lamprey spawning, baseline data, Condit Dam removal, tributaries, population sampling

Notes: A survey of the White Salmon River and its tributaries for Pacific and western brook lamprey populations to provide a baseline for comparison after the removal of Condit Dam. The document also looks at likely spawning areas for recolonizing Pacific lamprey after the removal of the dam.

Silver, G.S., Jolley, J.C., and Whitesel, T.A., 2010b, White Salmon River basin-Lamprey Project final programmatic report: U.S. Fish and Wildlife Service, Columbia River Fisheries Program Office, Vancouver, Washington, $26 \mathrm{p}$.

Keywords: lamprey population, lamprey habitat, lamprey spawning, baseline data, Condit Dam removal, tributaries, population sampling

Notes: A continuation of the previous report from 2007 to 2009 that adds data from 2010. Tables and discussion on the overall distribution of lamprey in the White Salmon River are included. 
Stampfli, Steve, 1993, Water temperature monitoring in Rattlesnake Creek: Underwood Conservation District, White Salmon data file, White Salmon, Washington, 2 p.

Keywords: water temperature, Rattlesnake Creek

Notes: Temperature data surveyed along the entire length of Rattlesnake Creek during a single day in August 1993.

Stampfli, Steve, 1994a, White Salmon river watershed basin land-use investigation report: Underwood Conservation District, White Salmon, Washington, 56 p.

Keywords: land use, historical land use, land ownership, maps, water quality, coliform bacteria, groundwater

Notes: A description of the use and ownership of land in the White Salmon River basin and its potential impact on water quality. Impacts include nonpoint-source pollution from cropland, livestock, orchard, forestland management, and residential use. It includes a map of the basin divided into subbasins and graphs showing the proportions of land types owned by different entities.

Stampfli, Steve, 1994b, White Salmon river watershed basin water quality investigation report: Underwood Conservation District, White Salmon, Washington, 56 p.

Keywords: water quality, baseline data, streamflow, coliform bacteria, hydrology, land use, restoration

Notes: This report contains baseline data on water quality in the White Salmon River during a testing period from 1992 through 1993. Data were gathered on bacteria concentrations, temperature, turbidity, dissolved minerals and metals, nitrates, hardness, dissolved oxygen, $\mathrm{pH}$, and other pollutants. The report includes recommendations for restoration in the river basin that could improve water quality by lowering concentrations of coliform bacteria throughout the basin and decreasing water temperatures in two tributaries.

Theisfeld, S.L., McPeak, R.H., and McNamara, B.S., 2001, Bull trout population assessment in the White Salmon and Klickitat Rivers, Columbia River Gorge, Washington: Washington Department of Fish and Wildlife, Annual Report to Bonneville Power Administration, Contract No. 00004474, Project No. 199902400, BPA Report DOE/BP-00004474-1, 77 p.

Keywords: bull trout (Salvelinus confluentus), snorkel survey, extirpation

Notes: An assessment that provides habitat data and descriptions of the minor creeks for tributaries of the White Salmon and Klickitat Rivers, including temperature, gradient, width, depth, substrate, LWD, and cover. It reports densities of fish species, including rainbow trout, western brook trout (Salvelinus fontinalis), and bull trout in each creek.

U.S. Environmental Protection Agency, 2008, Watershed Quality Assessment Report, Washington, Middle Columbia_-Hood Watershed: Web site, accessed April 18, 2012, at

http://iaspub.epa.gov/tmdl_waters10/attains_watershed.control?p_huc $=17070105 \& p \_s t a t e=W A \& p$ cycle $=\& p$ report_type $=T$.

Keywords: water quality, impaired waters, water temperature

Notes: This is a U.S. Environmental Protection Agency Web site with water quality reports for impaired rivers in the Middle Columbia River and Hood River basins, and the reasons for listing them as impaired. The White Salmon River and several of its tributaries are listed. All listings were for temperature, and some were for fecal coliform bacteria. 
U.S. Fish and Wildlife Service, 2002, Biological Opinion-Endangered Species Act consultation, Condit Hydroelectric Project: Lacey, Washington, 46 p.

Keywords: bull trout (Salvelinus confluentus), hydrology, ecology, fish habitat, water quality, sediment, Condit Dam removal, streambeds

Notes: The biological opinion issued by the U.S. Fish and Wildlife Service regarding impacts to federally listed bull trout habitat caused by the removal of Condit Dam. It includes information on bull trout life history and habitat in the White Salmon River basin.

U.S. Forest Service, 1991, Final environmental impact statement for the Lower White Salmon National Wild and Scenic River management plan: Hood River, Oregon, 339 p.

Keywords: management plan, socioeconomics, water quality, water use, resident fish, recreation, land use

Notes: An analysis of alternatives for management of the Lower White Salmon River and their potential environmental impacts.

U.S. Forest Service, 1996, Trout Lake Creek watershed analysis: Trout Lake, Washington, 96 p.

Keywords: hydrology, geology, ecology, vegetation, land use, tribal resources, cultural resources, erosion, water quality, water temperature, habitat, climate, streamflow, coliform bacteria, turbidity, stream channels, recommendations

Notes: A detailed analysis of the historical and current conditions of the Trout Lake Creek basin and the impacts of human use on these resources. The document includes a synthesis of management concerns and recommendations for each subbasin.

U.S. Forest Service, 1997a, Cave-Bear Creeks watershed analysis: Mt. Adams Ranger District, Gifford Pinchot National Forest report, Trout Lake, Washington, $150 \mathrm{p}$.

Keywords: geology, hydrology, vegetation, water quality, fish habitat, land use

Notes: The Cave-Bear Creek watersheds occupy about one-third of the upper White Salmon River basin. This report describes the historical and current conditions of several physical and biological factors within the Cave-Bear Creek basins.

U.S. Forest Service, 1997b, Upper White Salmon River Wild and Scenic River study report and final legislative environmental impact statement: Hood River, Oregon, 159 p.

Keywords: land use, river segments, streamflow, hydrology, ecology, geology, fish barriers, treaty rights, water quality

Notes: A comprehensive report examining the impacts of designation of the Upper White Salmon River under the Wild and Scenic Rivers Act. The report includes information on historical and current land ownership and land use in the area, as well as brief descriptions of each segment of the river, including fish resources and streamflow. 
U.S. Forest Service, 1998, Upper White Salmon River watershed analysis: Trout Lake, Washington, $193 \mathrm{p}$.

Keywords: water quality, hydrology, ecology, fish habitat, endangered species, land use, management plan, vegetation, streamflow.

Notes: The Upper White Salmon River basin occupies approximately one-quarter of the entire White Salmon River basin. This report describes the historical and current conditions of several physical and biological factors in the Upper White Salmon River basin. It includes data on peak and low streamflow and information on forest types and suitability for endangered species.

U.S. Forest Service), 2000, Upper White Salmon River watershed analysis: Mt. Adams Ranger District, Gifford Pinchot National Forest, Trout Lake, Washington, $135 \mathrm{p}$.

Keywords: geology, hydrology, vegetation, water quality, fish habitat, land use Notes: The Upper White Salmon River basin occupies approximately one-quarter of the entire White Salmon River basin. This report describes the historical and current conditions of several physical and biological factors within the Upper White Salmon River basin.

Washington Conservation Commission, 1999, Salmon and steelhead habitat limiting factors in WRIA 29: Lacey, Wash., Washington Conservation Commission, 57 p.

Keywords: limiting factors, habitat conditions, fish barriers, water quality, water use Notes: A discussion of habitat limiting factors in Water Resource Inventory Area (WRIA) 29 and priorities for restoration.

Washington Department of Wildlife, Confederated Tribes and Bands of the Yakama Indian Nation, and Washington Department of Fisheries 1990, White Salmon River subbasin salmon and steelhead production plan: Washington Department of Wildlife, Confederated Tribes and Bands of the Yakama Indian Nation and Washington Department of Fisheries, production plan, Olympia (State departments) and Toppenish (Yakama Nation), $138 \mathrm{p}$.

Keywords: supplementation, water quality, genetic stock identification, creel survey Notes: This report investigates plans to increase salmon production in the White Salmon River. It documents current production of salmonid fisheries and strategies for their increase. It includes results from creel surveys and genetic analyses of hatchery and wild rainbow trout.

Washington State Department of Ecology, 1990, Description of ambient water quality monitoring program for the state's surface water: Washington State Department of Ecology, Olympia, Washington, $35 \mathrm{p}$.

Keywords: water quality, water monitoring, raw data, streamflow, water analysis Notes: This report includes descriptions and maps of the State's water quality monitoring network and raw water quality data from 1960 to 1983 . 
Washington State Department of Ecology, 2001, Determination of significance and request for comment on scope of EIS and public notice of application for State of Washington water quality certification: Public Notice, Washington State Department of Ecology, Olympia, Washington, 12 p.

Keywords: Condit Dam removal, water quality, sediment

Notes: This is a public notice regarding the scope of the Environmental Impact Statement (EIS) and the water quality certification for the Condit Dam removal project. It includes a detailed description of the current dam structures and operation, and a description of the plan for dam removal.

Washington State Department of Ecology, 2007, Condit Dam Removal final SEPA supplemental environmental impact statement (FSEIS): Ecology publication \#07-06-012, Yakima, Washington, 249 p.

Keywords: State Environmental Policy Act (SEPA), Condit dam removal, land use, scenic resources Notes: An in-depth analysis of the environmental impacts associated with the removal of Condit Dam and plans for mitigation and post-removal management.

Watershed Professionals Network, 2003, WRIA 29 water rights and water use assessment: Prepared for Envirovision Corp. and WRIA Planning Unit, Bellingham, Washington, $121 \mathrm{p}$.

Keywords: Washington State Water Law, water use, water demand

Notes: An assessment of water rights, water use, and future projections of water demand of creeks and rivers within the Wind-White Salmon River Subbasin (WRIA 29). Numerous tables are included detailing water withdrawals, water use, and volumes.

Watershed Professionals Network and Mark Yinger Associates, 2002, WRIA 29 hydrology and geology assessment: Prepared for Envirovision Corp. and WRIA Planning Unit, Bellingham, WA, 62 p.

Keywords: climate, geology, hydrology, streamflow, land use

Notes: The report describes the geology, groundwater hydrology, and surface hydrology for the rivers and creeks of the Wind-White Salmon River subbasin (WRIA 29).

Weaver, Tim, 2002, Comments of the Confederated Tribes and Bands of the Yakama Nation on the draft supplemental final environmental impact statement: Confederate Tribes and Bands of the Yakama Nation, letter regarding application for a new license (FERC No. 2342), Toppenish, Washington, $15 \mathrm{p}$.

Keywords: Yakima Nation, Condit Dam removal, sediment, settlement agreement, PacifiCorp Notes: These are comments submitted by the Yakima Nation on the final Environmental Impact Statement (EIS) and settlement agreement with PacifiCorp regarding the removal of Condit Dam.

Western Watershed Analysts, 1994, An analysis of the thermal characteristics of Rattlesnake Creek in relation to the 303(d) listing process: Western Watershed Analysts, prepared for Champion International Inc., Lewiston, Idaho, 6 p.

Keywords: Rattlesnake Creek, canopy cover, water temperature, air temperature Notes: An analysis of temperature-controlling factors and water temperature data from Rattlesnake Creek. 
Western Watershed Analysts, 1997, Panakanic watershed analysis: Champion Pacific Timberlands, Inc., Lewiston, Idaho, 405 p.

Keywords: Rattlesnake Creek, hydrology, geology, water quality, ecology, land use, vegetation, streambeds, streamflow, erosion, water temperature, fish habitat, climate, maps

Notes: This comprehensive analysis of the Panakanic basin (Rattlesnake Creek) examines the geology, hydrology, and ecology of the basin with emphasis on improving riparian habitat and reducing erosion near streams. It includes data on stream gradient and geology for the rivers in the basin and a fish habitat assessment with maps and descriptions of historical and current ranges of anadromous fish.

White, Jim, and Cochrane, Tova, 2005, Assess current and potential salmonid production in Rattlesnake Creek associated with restoration efforts: Underwood Conservation District, 2005 Annual Report, Project No. 200102500, 31 p.

Keywords: water quality, streamflow, water temperature, fish habitat, maps

Notes: This report details results of sampling for water chemistry (that is, $\mathrm{pH}$, conductivity, dissolved oxygen, nitrates, phosphorus, and total suspended solids) and water temperatures. The sampling locations were the White Salmon River (rkm 2.5, 20, and 67), Buck Creek, Rattlesnake Creek, Indian Creek, Mill Creek, Gilmer Creek, Trout Lake Creek, and Cascade Creek.

Yinger, Mark, 1998, Aquifer test plan: Mark Yinger Associates, Parkdale, Oregon, 18 p.

Keywords: hydrology, maps

Notes: A report of aquifer testing for a prospective well in White Salmon, Washington. The paper includes maps and groundwater data.

Yinger, Mark, [no date], Buck Creek watershed critical aquifer recharge area definition for the city of White Salmon, Washington: Report of Mark Yinger Associates to Cascade Planning Associates, White Salmon, Washington, 4 p.

Keywords: Buck Creek, hydrology, geology, ground water

Notes: A brief report on the geology and hydrology of the Buck Creek watershed. It identifies critical recharge areas and the vulnerability to contamination of the sole source of potable water for the city of White Salmon.

\section{Acknowledgments}

We want to acknowledge Stuart Oberg, Patrick Norby, and Carrie Munz of USGS for their hard work helping to compile and organize the references.

\section{References Cited}

Allen, M.B., and Connolly, P.J., 2005, Assessment of the White Salmon watershed using the ecosystem diagnosis and treatment model: U.S. Geological Survey, Columbia River Research Laboratory, Cook, Washington, $55 \mathrm{p}$.

Allen, M.B., and Connolly, P.J., 2011, Composition and relative abundance of fish species in the Lower White Salmon River, Washington, prior to the removal of Condit Dam: U.S. Geological Survey Open-File Report 2011-1087, 32 p. 
Allen, M.B., Connolly, P.J., Jezorek, I.G., Munz, C., and Charrier, J.C., 2006, Assess current and potential salmonid production in Rattlesnake Creek in association with restoration efforts: U.S. Geological Survey 2004-2005 Annual Report, Project No. 200102500, BPA Report DOE/BP00005068-4, $101 \mathrm{p}$.

Bair, Brian, Grover, Dean, and Powers, Paul, 2002, Effects of the proposed Condit Dam removal on fish populations and habitat in the White Salmon Wild and Scenic River: USDA Forest Service report, Carson, Washington.

Beamish, R.J., 1980, Adult biology of the river lamprey (Lampetra ayresi) and the Pacific lamprey (Lampetra tridentata) from the Pacific coast of Canada: Canadian Journal of Fisheries and Aquatic Sciences, v. 45, p. 834-844.

Chapman, D.W., Platts, W.S., and Hill, M., 1990, Evaluation of introduction of anadromous salmonids upstream of Condit Dam in the White Salmon River, Washington: Boise, Idaho.

Close, D.A., Fitzpatrick, M.S., and Li, H.W., 2002, The ecological and cultural importance of a species at risk of extinction, Pacific lamprey: Fisheries, v. 27, no. 7, p. 19-25.

Collyard, Scott, 2011, White Salmon River watershed fecal coliform bacteria attainment monitoring study: Washington State Department of Ecology, Olympia, Washington, Publication No. 11-03-046, $74 \mathrm{p}$.

Haring, Donald, 2003, White Salmon River watershed addendum to Wind / White Salmon water resource inventory area 29 salmonid limiting factor analysis (originally issued July 1999):

Washington Conservation Commission, Olympia, Washington, 98 p.

Hennelly, Leslie, Delaere, Steve, and Jacobson, Susanne, 1994, White Salmon River stream survey report: Prepared for Underwood Conservation District, White Salmon, Washington, $50 \mathrm{p}$.

Jolley, J.C., Silver, G.S., and Whitesel, T.A., 2012a, Occurrence, detection, and habitat use of larval lamprey in the White Salmon River Basin pre-Condit Dam removal: 2011 annual report, U.S. Fish and Wildlife Service, Columbia River Fisheries Program Office, Vancouver, Washington, 21 p.

Jolley, J.C., Silver, G.S., and Whitesel, T.A., 2012b, Occurrence, detection, and habitat use of larval lamprey in Columbia River mainstem environments: Bonneville tailwater and tributary mouths: 2011 annual report, U.S. Fish and Wildlife Service, Columbia River Fisheries Program Office, Vancouver, Washington, $25 \mathrm{p}$.

Kan, T.T., 1975, Systematics, variation, distribution, and biology of lampreys of the genus Lampetra in Oregon: Corvallis, Oregon State University, Ph.D. dissertation, 207 p., accessed April 18, 2012, at http://hdl.handle.net/1957/17013.

Kostow, Kathryn, 2002, Oregon lampreys: natural history, status, and analysis of management issues: Oregon Department of Fish and Wildlife, Salem, Oregon, 113 p., accessed February 12, 2012, at http://www.fishlib.org/library/Documents/Oregon/DFW/lamprey.pdf

Land and Water Associates, 1989, A comparative evaluation of the geologic and hydrologic resource values on the Klickitat and White Salmon Rivers: Final report to USDA Forest Service, Hood River, Oregon, $22 \mathrm{p}$.

Luzier, C.W., Schaller, H.A., Brostrom, J.K., Cook-Tabor, C. Goodman, D.H., Nelle, R.D., Ostrand, K., and Streif, B., 2011, Pacific lamprey (Entosphenus tridentatus) assessment and template for conservation measures, U.S. Fish and Wildlife Service, Portland, Oregon, 282 p.

Morris, G.D., 2003, Assess current and potential salmonid production in Rattlesnake Creek associated with restoration efforts: Report prepared by Yakama Nation for the Bonneville Power Administration, BPA project ID No. 21009, Portland, Oregon, 51 p.

Morris, G.D., 2005, Assess current and potential salmonid production in Rattlesnake Creek associated with restoration efforts: Report prepared by Yakama Nation to Bonneville Power Administration, BPA project ID No. 17940, Portland, Oregon, 82 p. 
National Marine Fisheries Service, 2008, ESA recovery plan for the White Salmon River population of Middle Columbia River steelhead: National Marine Fisheries Service Northwest Region, Seattle, Washington, $118 \mathrm{p}$.

Normandeau Associates, 2004, White Salmon Subbasin plan: Prepared for the Northwest Power and Conservation Council, Portland, Oregon, 248 p.

Northwest Power and Conservation Council, 2004, StreamNet fish data for the Northwest-Subbasin planning: website, accessed April 18, 2012, at http://www.nwcouncil.org/fw/subbasinplanning/Default.htm.

Plummer, Emily, and Zuckerman, Adrianne, 2011, White Salmon River Watershed anadromous fish passage inventory 2009-2011 survey report: Underwood Conservation District, White Salmon, Washington, $53 \mathrm{p}$.

Pritchard, Don, Anderson, John, Correll, Cindy, Fogg, Jim, Gebhardt, Karl, Krapf, Russ, Leonard, Steve, Mitchell, Brenda, and Staats, Janice, 1998, Riparian area management-A user guide to assessing proper functioning condition and the supporting science for lotic areas: TR-1737-15, Bureau of Land Management, BLM/RS/ST-98/001+1737, National Applied Resource Sciences Center, Denver, Colorado.

Silver, G.S., Jolley, J.C., and Whitesel, T.A., 2010b, White Salmon River Basin: Lamprey Project final programmatic report: U.S. Fish and Wildlife Service, Columbia River Fisheries Program Office, Vancouver, Washington, $26 \mathrm{p}$.

Stampfli, Steve, 1994, White Salmon river watershed basin land-use investigation report: Underwood Conservation District, White Salmon, Washington, 56 p.

Torgersen, C.E., and Close, D.A., 2004, Influence of habitat heterogeneity on the distribution of larval Pacific lamprey (Lampetra tridentata) at two spatial scales: Freshwater Biology, v. 49, p. 614-630.

U.S. Forest Service, 1996, Trout Lake Creek watershed analysis: Trout Lake, Washington, 96 p.

U.S. Forest Service, 1997a, Cave-Bear Creeks watershed analysis: Mt. Adams Ranger District, Gifford Pinchot National Forest, Trout Lake, Washington, 150 p.

U.S. Forest Service, 1998, Upper White Salmon River watershed analysis: Trout Lake, Washington, $193 \mathrm{p}$.

Watershed Professionals Network, 2003, WRIA 29 water rights and water use assessment: Prepared for Envirovision Corp. and WRIA Planning Unit, Bellingham, Washington, $121 \mathrm{p}$.

Watershed Professionals Network and Mark Yinger Associates, 2002, WRIA 29 hydrology and geology assessment: Prepared for Envirovision Corp. and WRIA Planning Unit, Bellingham, Washington, $62 \mathrm{p}$.

Washington Department of Fisheries, U.S Fish and Wildlife Service, National Marine Fisheries Service, and Washington Department of Wildlife, 1989, The White Salmon River anadromous fish productivity potential: Olympia Washington.

Washington Department of Wildlife, Confederated Tribes and Bands of the Yakama Indian Nation, and Washington Department of Fisheries, 1990, White Salmon River Subbasin salmon and steelhead production plan: Washington Department of Wildlife, Confederated Tribes and Bands of the Yakama Indian Nation and Washington Department of Fisheries, production plan, Olympia (state departments) and Toppenish (Yakama Nation), 138 p.

Western Watershed Analysts, 1997, Panakanic watershed analysis: Champion Pacific Timberlands, Inc., Lewiston, Idaho, 405 p.

White, Jim, and Cochrane, Tova, 2005, Assess current and potential salmonid production in Rattlesnake Creek associated with restoration efforts: Underwood Conservation District, 2005 Annual Report, Project No. 200102500, 31 p. 


\section{Appendix A. Key Index}

\begin{tabular}{|c|c|}
\hline air temperature & historical distribution \\
\hline $\begin{array}{l}\text { Daseline data } \\
\text { Bonneville and The Dalles Dams }\end{array}$ & human impacts \\
\hline Bonneville and The Dalles Dams & Husum \\
\hline Buck Creek & hybridization \\
\hline bull trout (Salvelinus confluentus) & hydroelectric projects \\
\hline canopy cover & hydrology \\
\hline capture efficiency & impaired waters \\
\hline Chinook & improvement projects \\
\hline climate & Indian Creek \\
\hline coho & infrastructure \\
\hline coliform bacteria & irrigation \\
\hline comments & lamprey counts \\
\hline Condit Dam removal & lamprey habitat \\
\hline creel survey & lamprey occupancy \\
\hline critical habitat & lamprey population \\
\hline cultural resources & lamprey restoration \\
\hline dam proposals & lamprey spawning \\
\hline deepwater sampling & lamprey translocation \\
\hline disease profiling & land ownership \\
\hline distinct population segment & land use \\
\hline ecology & life history \\
\hline endangered species & limiting factors \\
\hline energy development & macroinvertebrate \\
\hline environmental analysis & Major Creek \\
\hline erosion & Major Population Groups (MPGs) \\
\hline ethnography & management \\
\hline extirpation & management plan \\
\hline fish barriers & maps \\
\hline fish distribution & Mill Creek \\
\hline fish habitat & mitigation \\
\hline fish management & natural resources \\
\hline fish populations & nuclear powerstation \\
\hline fish species composition & Oncorhyncus clarki \\
\hline focal species & oral history \\
\hline genetic diversity & outreach \\
\hline genetic stock identification & Pacific lamprey \\
\hline geology & PacifiCorp \\
\hline gradient & population sampling \\
\hline groundwater & precipitation \\
\hline habitat conditions & productivity \\
\hline historical impact mechanisms & rainbow trout \\
\hline historical land use & Rattlesnake Creek \\
\hline historical salmon runs & raw data \\
\hline historical Tribal lands & recommendations \\
\hline historical water quality & recreation \\
\hline
\end{tabular}


reservoir

resident fish

resource analysis

restoration

river segments

rotary screw trap

salmon potential

salmonid population modeling

scenic resources

sediment

settlement agreement

snorkel survey

socioeconomics

spawning areas

springs

State Environmental Policy Act (SEPA)

steelhead

storage alternatives

stream channels

stream condition inventories (SCI)

stream enhancement

streambeds

streamflow

subbasin plan

summer and winter steelhead

supplementation

treaty rights

Tribal affiliations
Tribal commerce

Tribal fishing grounds

Tribal fishing methods

Tribal languages

Tribal resources

tributaries

turbidity

unscreened diversions

vegetation

viability criteria

Washington State Water Law

wastewater treatment

water analysis

water demand

water diversion

water monitoring

water quality

water resource management

water temperature

water use

waterfalls

Wild and Scenic Rivers

Yakima Nation 
Publishing support provided by the U.S. Geological Survey

Publishing Network, Tacoma Publishing Service Center

For more information concerning the research in this report, contact the Director, Western Fisheries Research Center

U.S. Geological Survey

6505 NE 65th Street

Seattle, WA 98115

http://wfrc.usgs.gov/ 


\section{鸪}

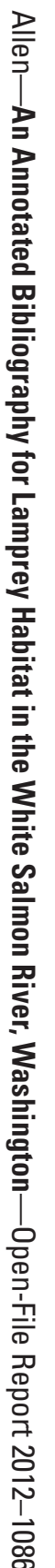

